\title{
Impact of Social Media Marketing in Small and Medium Business
}

Dr. Reena Shyam, Associate Professor, Indian Academy School of Management Studies reenashyam1@gmail.com

\begin{abstract}
Technology today is offering the best of its benefits to the users. The technology medium today is more visible and allows usage beyond borders overcoming many hurdles over a period of time and has influenced the world of marketing. Over the last few years social media has completely changed the way internet could be used in business. The users of social media are aware of various social media platforms like Facebook, Instagram, YouTube, Pintrest, Twitter, Watsapp etc.,. Today Facebook is still single important platform for most people to socially network for business or personal purpose. Business Enterprises large, medium or small today are using social media marketing for reaching the internet audience on cross devices. Communication occurs firstly in business to business(B2B) or business to customers (B2C) using social media as their first choice of preference. There is change in the ways how business owners think and purchasing styles of customers occur. This study aims to understand the impact of social media marketing[SMM] and how it has helped the small and medium business enterprises.
\end{abstract}

Keywords: Small and Medium business, Social Media, Social Media Marketing.

\section{Introduction}

Social media platforms help in establishing emotional connection between the company and their prospects. It further helps in improving the customer relationship management instantly when the business organisation is active on social media. Business Organisation and owners are aware about the availability of technology at affordable costs, ease of usage and benefits of measure. Small and Medium Business enterprises across the world are making the best use of technological benefits. The technology medium today is more visible and allows usage beyond borders overcoming many hurdles over a period of time and has influenced the world of marketing. Over the last few years social media has completely changed the way internet could be used in business. The users of social media are aware of various social media platforms like Facebook, Instagram, YouTube, Pintrest, Twitter, Watsappetc.,. Today Facebook is still single important platform for most people to socially network for business or personal purpose. Business Enterprises large, medium or small today are using social media marketing for reaching the internet audience on cross devices. Communication occurs firstly in business to business(B2B) or business to customers(B2C) using social media as their first choice of preference. There is change in the ways how business owners think and purchasing styles of customers occur. 
WORLD INTERNET USAGE AND POPULATION STATISTICS AS ON DEC 31, 2017

\begin{tabular}{|l|l|l|l|l|l|l|}
\hline $\begin{array}{l}\text { World } \\
\text { Regions }\end{array}$ & $\begin{array}{l}\text { Population } \\
\text { ( 2018 Est.) }\end{array}$ & $\begin{array}{l}\text { Population } \\
\text { \% of World }\end{array}$ & $\begin{array}{l}\text { Internet Users } \\
\text { 31 Dec 2017 }\end{array}$ & $\begin{array}{l}\text { Penetration } \\
\text { Rate (\% Pop.) }\end{array}$ & $\begin{array}{l}\text { Growth } \\
\mathbf{2 0 0 0 - 2 0 1 8}\end{array}$ & $\begin{array}{l}\text { Internet } \\
\text { Users \% }\end{array}$ \\
\hline Africa & $1,287,914,329$ & $16.9 \%$ & $453,329,534$ & $35.2 \%$ & $9,941 \%$ & $10.9 \%$ \\
\hline Asia & $4,207,588,157$ & $55.1 \%$ & $2,023,630,194$ & $48.1 \%$ & $1,670 \%$ & $48.7 \%$ \\
\hline Europe & $827,650,849$ & $10.8 \%$ & $704,833,752$ & $85.2 \%$ & $570 \%$ & $17.0 \%$ \\
\hline $\begin{array}{l}\text { Latin America } \\
\text { / Caribbean }\end{array}$ & $652,047,996$ & $8.5 \%$ & $437,001,277$ & $67.0 \%$ & $2,318 \%$ & $10.5 \%$ \\
\hline Middle East & $254,438,981$ & $3.3 \%$ & $164,037,259$ & $64.5 \%$ & $4,893 \%$ & $3.9 \%$ \\
\hline North America & $363,844,662$ & $4.8 \%$ & $345,660,847$ & $95.0 \%$ & $219 \%$ & $8.3 \%$ \\
\hline Oceania / Australia & $41,273,454$ & $0.6 \%$ & $28,439,277$ & $68.9 \%$ & $273 \%$ & $0.7 \%$ \\
\hline WORLD TOTAL & $\mathbf{7 , 6 3 4 , 7 5 8 , 4 2 8}$ & $\mathbf{1 0 0 . 0} \%$ & $\mathbf{4 , 1 5 6 , 9 3 2 , 1 4 0}$ & $\mathbf{5 4 . 4 \%}$ & $\mathbf{1 , 0 5 2} \%$ & $\mathbf{1 0 0 . 0 \%}$ \\
\hline
\end{tabular}

The above table shows that Asia leads with $48.7 \%$ internet userswhich itself is a bug opportunity to business enterprises to connect and communicate through social media. Business enterprises have to source out their intentions like engaging, creating awareness or performance which they need to achieve using these social media to deliver their product and services related information.

\section{INTERNET USERS IN THE WORLD BY GEOGRAPHIC REGIONS}

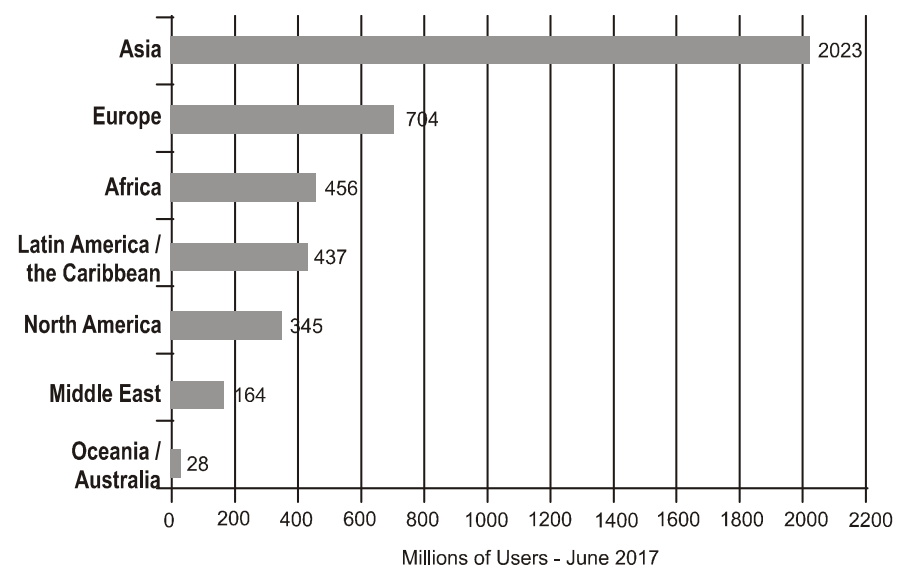

Source: Internet World Stats - www.internetworldstats.com/stats.htm Basis: 4,156,932,140 internet users estimated in December 31, 2017

\section{Statement of the problem}

Social media is successful and economical: Social media marketing is vital for organizations as a result of its reasonableness and capacity to achieve countless groups of onlookers inside less time. Organisation today have both benefits and disadvantages when they adopt to social platform requirements with their business intentions. Small and Medium Sector enterprises must formulate and align marketing strategies keeping the technological and social media approach as preferred by their customers. There are many spammers on the social media sites who try to bring down the image of the brand. But handling and tackling such situations becomes a major task of the administrator of the page or the in charge of a brand page from its own organization. This paper is an attempt to explore factors influencing small and medium business entities using of social media.

\section{Review of Literature}

Haslinda and Fadhlur(2016) discuss various factors that influence performance which is connected with the effectiveness of customer engagement, image reputation of the brand and brand attitude of the customers towards the online performance of medium and small Enterprises. According to the research, the Internet has contributed around 41 to $42 \%$ of the national economy and respectively increasing every 3 years. It shows how social media marketing connect with the customer and business simultaneously checking out the customer engagement with the business the structure in 


\section{Entrepreneurship and Startups}

appearance of the product indicates the brand reputation and also the image of the brand which in turn associates with the customer brand attitude towards a brand with the social media as a medium of interaction. Basically, they are concerned about how online a semi performance are interlinked with customer engagement brand reputation and image also the brand attitudes of the customer and it is also stated that customer satisfaction and loyalty factors that influence are the factors that influence brand attitudes.Charity Pradiptarini (2011) talks about social media marketing as how it measures the effectiveness and also identifying the target audience or the target market. With the increasing popularity of social media, many companies and firms have adapted this as a part of the strategy to spread recognition of product and services that are being delivered. Facebook is well established for both business and to maintain relationship with friends as well as customers/consumers compared to Twitter or Myspace or Linkedln and others. Basic effectiveness increases in social media marketing through the content quality and not through the quantity while at the same time building trust and long term relationship is simultaneously important. Sharad Malhotra(2016) quotes that social media in other words is also called as consumer generated media, which gives ample opportunities not only to communicate but also to interact by likes, dislikes, demand and supply with consumer directly without any intermediation. It is not a monologue but a dialogue between people sharing similar interests and hobbies. It has created openness among the users to interact freely between the groups and share their views by providing connectedness.

\section{Objectives of the Study}

Social Media plays a vital role in the marketing field. It can grab the audience's attention through various social media platforms and curate them towards the brand and engage them. This study is conducted to explore various factors that have impact on social media marketing[SMM] in the small and medium business in the changing business scenario.

\section{Methodology}

This is an Exploratory Research. 100 number of Randomly selected respondents who had either small or medium business were administered with questionnaires comprising 18 questions. Primary Data was collected through personal interviews, discussion and meetings with respondents. Secondary Data was collected from journals and magazines for in depth knowledge of the social media marketing, websites, text books, newspaper were also sourced. Data collected from respondents was analysed with tables and charts using MS Office Excel Software.

\section{Limitation of Study}

This study came across a limitation where few of the respondents did not reveal the right information due to less knowledge of social media usage.

\section{Results and Discussion}

Demographic data

Table 1

\begin{tabular}{|l|l|l|}
\hline \multirow{4}{*}{ Gender } & Male & 66 \\
\cline { 2 - 3 } & Females & 34 \\
\cline { 2 - 3 } (in Rs) & Total & 100 \\
\hline \multirow{5}{*}{$\begin{array}{l}\text { Business Income } \\
\text { in Business }\end{array}$} & 1-3 Lakhs & 26 \\
\cline { 2 - 3 } & 4-6 Lakhs & 53 \\
\cline { 2 - 3 } & 7-10 Lakhs & 12 \\
\cline { 2 - 3 } & Above 10 Lakhs & 9 \\
\cline { 2 - 3 } & Total & 100 \\
\hline \multirow{5}{*}{ Qualification } & $<2$ years & 4 \\
\cline { 2 - 3 } & $2-4$ years & 12 \\
\cline { 2 - 3 } & $5-7$ years & 36 \\
\cline { 2 - 3 } & Above 7 years & 48 \\
\cline { 2 - 3 } & Total & 100 \\
\hline & Upto PUC & 24 \\
\cline { 2 - 3 } & Graduate & 55 \\
\cline { 2 - 3 } & Post Graduation & \\
\hline & Or above & 21 \\
\cline { 2 - 3 } & Total & 100 \\
\hline Type of business & Small & 63 \\
\cline { 2 - 3 } & Medium & 37 \\
\cline { 2 - 3 } & Total & 100 \\
\hline
\end{tabular}




\section{Entrepreneurship and Startups}

\begin{tabular}{|l|ll|}
\hline Number of staff & $<2$ & 12 \\
\cline { 2 - 3 } & $3-6$ & 35 \\
\cline { 2 - 3 } & $7-10$ & 35 \\
\cline { 2 - 3 } & Above 10 & 12 \\
\hline
\end{tabular}

Social Media Awareness

Table 2

\begin{tabular}{|l|l|}
\hline Particulars & Number of Users \\
\hline Facebook & 100 \\
\hline Twitter & 100 \\
\hline Linkedln & 100 \\
\hline Google+ & 61 \\
\hline YouTube & 100 \\
\hline Instagram & 72 \\
\hline
\end{tabular}

Usage of Social Media Sites / Apps for Business purpose.

Table 3

\begin{tabular}{|l|l|}
\hline Particulars & Number of Users \\
\hline Yes & 48 \\
\hline No & 52 \\
\hline Total & 100 \\
\hline
\end{tabular}

Table 2 \& 3 reveals that Social Media like Facebook, Twitter, YouTube and LinkedIn are aware to all respondents. But only $48 \%$ of respondents are using the Social Media Sites or Apps for their business purpose.

Usage of Social Media Sites / Apps for Social Media Marketing.

Table 4

\begin{tabular}{|l|l|}
\hline Social Media & Number of Users \\
\hline Facebook & 42 \\
\hline Twitter & 3 \\
\hline Linkedln & 12 \\
\hline Google+ & 2 \\
\hline YouTube & 0 \\
\hline Instagram & 28 \\
\hline
\end{tabular}

Table 4 exhibits the usage of various Social Media Sites / Apps for Social Media Marketing in which Facebook is used by majority of respondents.

If No, choose the reason

Table 5

\begin{tabular}{|l|l|}
\hline Particulars & Number of Users \\
\hline Never heard of these sites & 4 \\
\hline Not interested & 12 \\
\hline Against my culture & 0 \\
\hline No time for social media & 24 \\
\hline Scared being on social sites & 12 \\
\hline Total & 52 \\
\hline
\end{tabular}

Out of 52 respondents who aren't on social media sites stated the following reasons: $4 \%$ saying that they have never heard of these sites \& $12 \%$ not interested. $24 \%$ of those stated, no time for social media and $12 \%$ scared of being on social media sites. None stated using Social Media was against their culture.

Device used to access social media site

Table 6

\begin{tabular}{|l|l|}
\hline Device & Percentage \\
\hline PC & 22 \\
\hline Laptop & 12 \\
\hline Smartphone & 83 \\
\hline Tab/iPod & 0 \\
\hline
\end{tabular}

In Table 6 it is seen that $22 \%$ of the respondents use PC, $12 \%$ use laptop and $83 \%$ using smartphones to access social media sites.

Purpose of using Social Media Sites.

Table 7

\begin{tabular}{|l|l|}
\hline Purpose & Number of Users \\
\hline Create Brand Awareness & 9 \\
\hline To sell & 36 \\
\hline Customer Engagement & 20 \\
\hline Networking & 9 \\
\hline Others & 26 \\
\hline Total & 100 \\
\hline
\end{tabular}




\section{Entrepreneurship and Startups}

It is seen from above Table $7,36 \%$ of respondents are using Social Media to Sell, and 20\% for customer engagement.

Key Findings :

Majority access social media sites on daily basis and smartphones have become major access tool by which they stay active on social media to build their business. $40 \%$ of them are active during night time and only $2 \%$ of them are active during noon.32\% of them are present in between 7 to 8 relevant business groups. $42 \%$ of the respondents are highly concerned about protecting their intimate secrets.

$50 \%$ of the respondents said that their favourite page is Movies genre, $80 \%$ said it is news page, $72 \%$ it is science and technology, $18 \%$ games, $52 \%$ for photography, $48 \%$ for politics and $16 \%$ said others.

\section{Conclusion and Suggestions}

Though there is usage of social media their fear of being present on social media, ignorance of trends the social media is catching up by saying no time for social media usage would have an impact on their business in future. Many of Small and medium Sellers feel that social media is for selling and are not still aware of benefits of social media due to less usage. This may change in the future as most customers expect information and check for Reviews (both negative and positive), Likes and Comments.

\section{References:}

1 Haslinda Musa, Fadhlur Rahim Azmia, Namirah Ab Rahima, Abdul Samad, Shibghatullaha, NorfaridatulAkmaliahOthmana,(2016) Analyzing the Effectiveness of Social Media Marketing, International Review of Management and Marketing, ISSN: 2146-4405, 2016, 6(S7) 1-5.
2 Charity Pradiptarini,(2011), Social Media Marketing: Measuring Its Effectiveness and Identifying the Target Market, UW-L Journal of Undergraduate Research XIV (2011),

3 Sharad Malhotra, 2016, Social Media: A New Communication Medium in Marketing, Gyan Management, Vol10, Issue 2 (Jul-Dec 2016).

4 Bihari Suresh Chandra (2011), Redifining MSME with CRM practices, ISSN:2231-2463, pp51-pp52

5 Mayank Yadav(2017), Social Media as a Marketing Tool : Opportunities and Challenges, Indian Journal of Marketing, Volume 47, Issue 3, March 2017

6 Holly Paquette, Social Media as a Marketing Tool: A Literature Review, :http:// digitalcommons.uri.edu/tmd_major_papers

7 Anthony Patino, Social media's emerging importance in market research, Journal of Consumer Marketing Volume 29, Issue 3

8 You, Ya, Vadakkepatt, Gautham G., and Joshi, Amit M. (2015), "A Meta-Analysis of Electronic Word-of-Mouth Elasticity," Journal of Marketing, 79 (2), 19-39

9 We Are Social (2014), Global Social Media Users Pass 2 Billion, http://wearesocial.net/blog/2014/ 08/global-social-media-users-pass-2-billion/ 